\title{
Intersemiotic translation and transformational creativity
}

\author{
Daniella Aguiar, Pedro Atã and João Queiroz
}

\begin{abstract}
In this article we approach a case of intersemiotic translation as a paradigmatic example of Boden's 'transformational creativity' category. To develop our argument, we consider Boden's fundamental notion of 'conceptual space' as a regular pattern of semiotic action, or 'habit' (sensu Peirce). We exemplify with Gertrude Stein's intersemiotic translation of Cézanne and Picasso's proto-cubist and cubist paintings. The results of Stein's IT transform the conceptual space of modern literature, constraining it towards new patterns of semiosis. Our association of Boden's framework to describe a cognitive creative phenomenon with a philosophically robust theory of meaning results in a cognitive semiotic account of IT.
\end{abstract}

KEYWORDS Intersemiotic translation; Creativity; Gertrude Stein; Charles S. Peirce; Margaret A. Boden

\section{Introduction}

Intersemiotic translation (IT) is a phenomenon of interest in many fields of research such as Comparative Literature, Translation Studies, General Semiotics, and Intermedial Studies. It has been called adaptation (Clüver 2011), intersemiotic transposition (Clüver 2006), medial transposition (Rajewsky 2005) and so on. Each term emphasizes a slightly different aspect of the phenomenon. IT was first defined by Roman Jakobson (2000 [1959]: 114) as 'an interpretation of verbal signs by means of signs of nonverbal sign systems'. Currently, the term designates relations between systems of different natures, and it is not restricted to the interpretation of verbal signs. Consequently, this process is observed between several semiotic phenomena, including literature, cinema, comics, poetry, dance, music, theater, sculpture, painting, video, and so on.

It is well known that several experimental artists who have creatively transformed their fields dedicated themselves to the intersemiotic translation of methods and aesthetic procedures from one sign system into another - Gertrude Stein translated Cézanne and Picasso's proto-cubist and cubist approaches into literature; Kandinsky translated Arnold Schoenberg's methods into painting (Weiss 1997); Morton Feldman translated abstract expressionism's formal procedures into music (Kissane 2010); Paul Klee translated polyphony's music structures into painting (Verdi 1968); Augusto de Campos translated Anton Webern and Klangfarbenmelodie models into concrete poetry (Clüver 1981). Nevertheless, to consider an IT creative is often a matter of personal taste. In fact, creativity has often been associated with mysterious, inexplicable, or vaguely formulated concepts such as appeals to 'talent or gift', 'subjective expression', 'intuition', 'inspiration' or 'genius'. A common view is that creativity possesses an unaccountable element of subjectivity and cannot be scientifically explained (see Sternberg and Lubart 1999, Magnani 2005). 
Here we approach a case of IT as a paradigmatic example of Boden's 'transformational creativity' category: 'some transformation of one or more of the (relatively fundamental) dimensions defining the conceptual space concerned' (Boden, 2010: 29). To develop our argument, we consider Boden's fundamental notion of 'conceptual space' as a regular pattern of semiotic action, or 'habit' (sensu Peirce). For Boden:

A conceptual space is defined by a set of enabling constraints, which make possible the generation of structures lying within that space [...]. If one or more of these constraints is altered (or dropped), the space is transformed. Ideas that previously were impossible (relative to the original conceptual space) become conceivable. (Boden 1999: 352)

These sets of enabling constraints define 'structured styles of thought' such as 'ways of writing prose or poetry; styles of sculpture, painting, or music; theories in chemistry or biology; fashions of couture or choreography, nouvelle cuisine and good old meat-and-two-veg' (Boden 2012: 32). To give a more precise philosophical framework to the definition of conceptual space we suggest the notion of 'habit'. Peirce's notion of habit can be defined as a constraining factor of semiotic behavior (see below). In our description, Boden's 'set of enabling constraints' constitutes habits, so that conceptual spaces are defined by habits. We characterize IT as a semiotic process (Aguiar and Queiroz, 2010,2013 ) of communication of habits from one conceptual space to another. In transformational IT (ITs involved in transformational creativity) the effect of the communication is the alteration of the habits of the target conceptual space.

In the next section we introduce intersemiotic translation and the Peircean notion of habit. Subsequently, we relate intersemiotic translation and the transformation of conceptual spaces, following Boden's typology of creativity. In the final section, we examine the case of Gertrude Stein's intersemiotic translation of Cézanne and Picasso's proto-cubist and cubist painting as a case of transformational creativity.

\section{Intersemiotic translation as a communication of habits}

As we have argued in other works (Queiroz and Aguiar 2015; Aguiar and Queiroz 2013, 2010), intersemiotic translation is a semiotic process (semiosis, or sign action). According to Peirce's model, any description of semiosis involves a relational complex constituted by three terms irreducibly connected - Sign, Object and Interpretant (S-O-I) (see Bergman and Queiroz 2014). The irreducibility indicates a logical property of this complex: the sign process must be regarded as associated to the interpretant, as an ongoing process of interpretation (see Hausman 1993: 9), and is not decomposable into any simpler relation. A sign is pragmatically defined as a medium for the communication to the interpretant of a form embodied in the object, so as to constrain, in general, the interpreter's behavior. For Peirce,

[...] a Sign may be defined as a Medium for the communication of a Form [...]. As a medium, the Sign is essentially in a triadic relation, to its Object which determines it, and to its Interpretant which it determines [...]. That which is communicated from the Object through the Sign to the Interpretant is a Form; that is to say, it is nothing like an existent, but is a power, is the fact that something would happen under certain conditions. (MS 793:1-3. See EP 2.544, n.22, for a slightly different version $)^{1}$

The object of sign communication is a form, or habit (or a 'pattern of constraints') embodied as a constraining factor of interpretative behavior - a logical 'would be' fact of response (see Queiroz and El-Hani 2004). ${ }^{2}$ The habit is something that is embodied in the object as a regularity, a 'disposition' (CP 2.170) (De Tienne 2003; Hulswit 2001). The notion of semiosis as habit, communicated from the object to the interpreter through the mediation of the sign, allows us to conceive meaning in a pro- 
cessual, non-substantive way, as a constraining factor of possible patterns of interpretative behavior (Queiroz and El-Hani 2006) (see Figure 1).

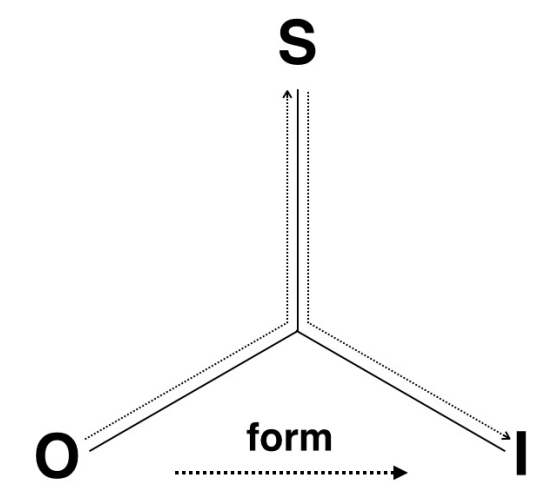

Figure 1. Semiosis as a relation between three irreducibly connected terms (sign-object-interpretant, S-O-I). This triadic relationship communicates/conveys a form from the object to the interpretant through the sign (symbolized by the horizontal arrow). The other two arrows indicate that the form is conveyed from the object to the interpretant through a determination of the sign by the object, and a determination of the interpretant by the sign.

Peirce's habit entails a disposition to act in certain ways under certain circumstances, especially when the carrier of the habit is stimulated, animated, or guided by certain motives (CP 5.480).

... all things have a tendency to take habits. For atoms and their parts, molecules and groups of molecules, and in short every conceivable real object, there is a greater probability of acting as on a former like occasion than otherwise. This tendency itself constitutes a regularity, and is continually on the increase. In looking back into the past we are looking toward periods when it was a less and less decided tendency. But its own essential nature is to grow. It is a generalizing tendency; it causes actions in the future to follow some generalization of past actions; and this tendency is itself something capable of similar generalizations; and thus, it is self-generative. (CP1.409, circa 1890, from 'A guess at the riddle', reprinted in EP1: 277)

A Habit involves a general 'would be' relation, which is not reducible to any number of its instances:

...by a Habit I shall mean a character of anything, say of B, this character consisting in the fact that under circumstances of a certain kind, say A, B would tend to be such as is signified by a determinate predicate, say C. (MS [R] 681:22)

...no agglomeration of actual happenings can ever completely fill up the meaning of a 'would-be'. (EP 2:402; CP 5.467)

...no collection whatever of single acts, though it were ever so many grades greater than a simple endless series, can constitute a would-be, nor can the knowledge of single acts, whatever their multitude, tell us for sure of a would-be. (1910 | Note (Notes on Art. III) [R] | CP 2.667)

Intersemiotic translation can be described as a fundamentally triadic phenomenon of communication of habits. As the intersemiotic translation is a semiotic process by definition, and semiosis is understood as a relation in which Sign, its Object and its Interpretant are its main constitutive elements that cannot be reduced any further, we can determine specific situations in which this relation can take place in different configurations. Aguiar and Queiroz (2010) propose two different models of intersemiotic translation based on the triadic relation between S-O-I. In the first model: 'the sign 
is the semiotic source (translated work). The object of the translated sign is the object of the semiotic-source, and the interpretant (produced effect) is the translator sign (semiotic target)' (see Figure 2):

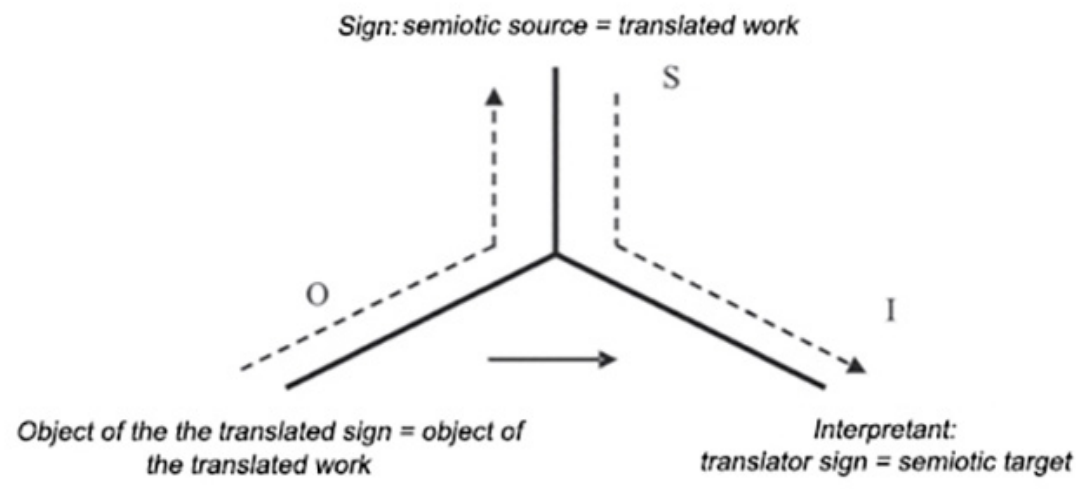

Figure 2. Triadic relation in which the sign is the translated work, the object of the sign is the object of the work, and the interpretant is the translator sign.

In the second model, 'the sign is the semiotic target. The object of the sign is the translated work, and the interpretant is the effect produced on the interpreter (interpretant)'. (Aguiar and Queiroz 2010) (Figure 3):

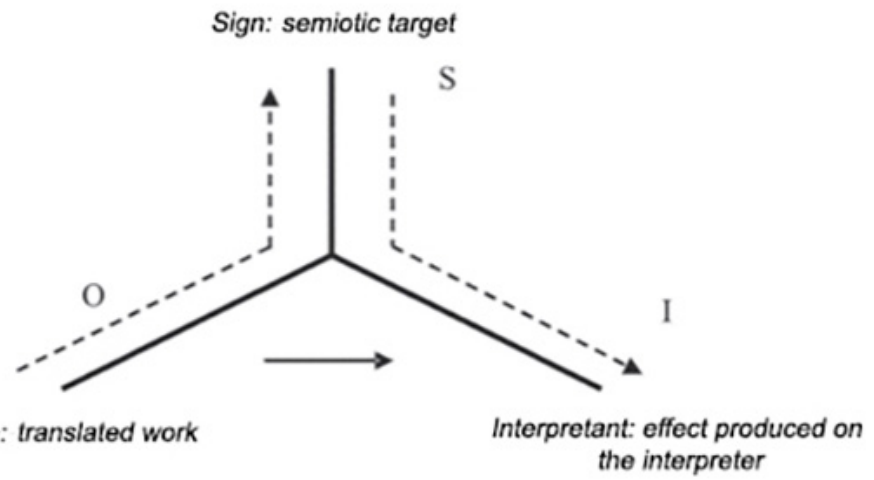

Figure 3. Triadic relation in which the sign is the target, the object of the sign is the translated work, and the interpretant is the effect produced on the interpreter.

A triadic model of IT brings about some interesting consequences. First, as 'sign', 'object' and 'interpretant' are functional roles of a triadic relation, anything that can be in such a relation can participate in the translation. Thus, in an IT, sign and object can be artworks, series of artworks, procedures, properties, or even semiotic phenomena from other fields such as scientific models; similarly, the interpreter can be an individual mind, but also a group of people (e.g. art historians), and many others. Second, as the three entities of the sign action cannot be dissociated, an IT will be considered as such depending on the interpreter and his/her context (such as in interpretative conventions). Third, as meaning is a relational property and not something 'fixed' or 'inherent' in a sign, that which is intersemiotically translated is not 'meaning' in the sense of a conveyed 'message', but a habit which can lead to the emergence of other potentially infinite meaning relations (though not any meaning relation, because of the regular nature of the habit itself).

Here we will explore the second model to describe a transformational IT (Figure 3, above), where the interpreter is the conceptual space of modern literature. 


\section{Intersemiotic Translation and Creativity}

Although IT can be considered a widely spread artistic practice nowadays, as far as we know, it has not been theoretically framed as a creative phenomenon. 'Creative' and 'creativity' are terms of ordinary discourse that are used in unsystematic and inconsistent ways - 'It is plain, nevertheless, from the wealth of academic writing on creativity that there is a widespread belief, or perhaps hypothesis, amongst philosophers, psychologists, and others that such a concept can be defined' (Ritchie 2005). We will base the development of our argument on Margaret Boden's ideas on creativity. She defines creativity as:

the ability to come up with ideas or artefacts that are new, surprising, and valuable. 'Ideas', here, include concepts, poems, musical compositions, scientific theories, cooking recipes, choreography, jokes....and so on, and on. 'Artefacts' include paintings, sculpture, steam engines, vacuum cleaners, pottery, origami, penny whistles...and you can name many more. (Boden 2010: 29)

According to her approach, there are three categories of creativity: combinatorial, exploratory, and transformational (Boden 2010). ${ }^{4}$ The first type is related to new things that arise within a combinatorial process of familiar ideas or artefacts. The second consists in the exploration of particular conceptual spaces, such as concrete poetry, constructivist painting, postmodern dance, and so on. And the third type of creativity 'involves some transformation of one or more of the (relatively fundamental) dimensions defining the conceptual space concerned' (Boden 2010: 29). The transformation of conceptual spaces occurs through an otherwise impossible idea that "can come about only if the creator changes the pre-existing style in some way, [...] so that thoughts are now possible which previously (within the untransformed space) were literally inconceivable' (Boden 2010: 34).

Applying Boden's terminology, IT is a semiotic relation, as modeled in the section above, between different conceptual spaces: from cubist literature to contemporary dance, from surrealist painting to automatic writing, from dodecaphonic music to abstractionist painting, and so on. Some IT cases can be considered transformational creativity phenomena. By translating from different conceptual spaces they create something new, surprising and valuable in their own conceptual space, transforming it and creating new possibilities to be explored. ${ }^{5}$

\section{Transformational Creative Intersemiotic Translation: Gertrude Stein}

Here we are interested in IT as a way to transform the target conceptual space by translating aspects, properties, or methods from another (source) conceptual space. One good example, mentioned before, is Gertrude Stein's IT from cubism in painting to literature. Stein (1874-1946) is among the most radical of the early twentieth-century literary Modernists. Her work was influenced by William James, her teacher at Harvard Annex, who directed her literary experiments toward questions about personality, consciousness, and perception of time (Levinson 1941; Dubnik 1984; Hoffman 1965). Intersemiotically, her writing translated the compositional techniques developed by Paul Cézanne and Pablo Picasso, creating a proto-cubist conceptual space in literature (see Hilder 2005; Fitz 1973; Perloff 1979).

The results of Stein's transformational IT are new, surprising, and valuable. Respectively, they inaugurate new habits in the conceptual space of Modernist literature; force the reader to drop conventional ideas about the previously established conceptual space; and converted Stein to be widely considered one of the most influential writers of the twentieth century. 
Novelty in Stein's transformational IT is related to the translation of the perspective flatness of Cézanne's paintings to experimental texts such as Three Lives, The Making of Americans, and in the subsequent portraits, such as Picasso (1909), Orta or One Dancing (1912) or A Valentine to Sherwood Anderson (1922) (see Abreu, 2008: 40; Hilder, 2005: 73). In Cézanne's work, perspective flatness ruptures the visual hierarchy that had structured pictorial composition since the Renaissance. In Stein's IT, perspective flatness is translated as no difference in relative importance of different parts of the text, as observed in the absence of climax (Weinstein 1970). This translation also affects syntax (and, at the same time, results from Stein's syntactical experiments), since all words are considered equally relevant irrespective of their structural functions. Weinstein (1970: 37) notes that '[...] not only will people and objects have the same importance, but all time passages will be of equal importance'.

Surprise in Stein's transformational IT is related to the translation of Cézanne's meta-painting: critique and questioning of the conceptual space of painting through the painting itself, forcing the viewer to drop conventional ideas about what a painting is. Similarly, Stein's The Making of American's '[...] is a meta-novel that makes us question not only the shape of the novel form itself but the nature of the medium, the linguistic 'paint' that the writer applies to create a world' (Weinstein 1970: 45).

Many authors attest the value of Stein's works; they consider her one of the most important writers of Modernist literature (Retallack 2008; Gass 1995). Stein's transformational IT has clearly influenced the work of different writers such as Ernest Hemingway (Nath and Matthes 2005) and Richard Wright (Weiss 1998). However, her work was not well received in its time (see Franken 2000). She had bad answers from editors and negative reception from readers and critics, which is arguably due to the transformational character of her work causing difficulty in its reception inside the conceptual space yet to be transformed.

But why is Gertrude Stein's work an example of transformational IT? Stein's works (sign) have created new possibilities in writing (interpretant) because of the communication of habits from cubist and proto-cubist painting (object) (see Figure 4).

\section{Gertrude Stein}

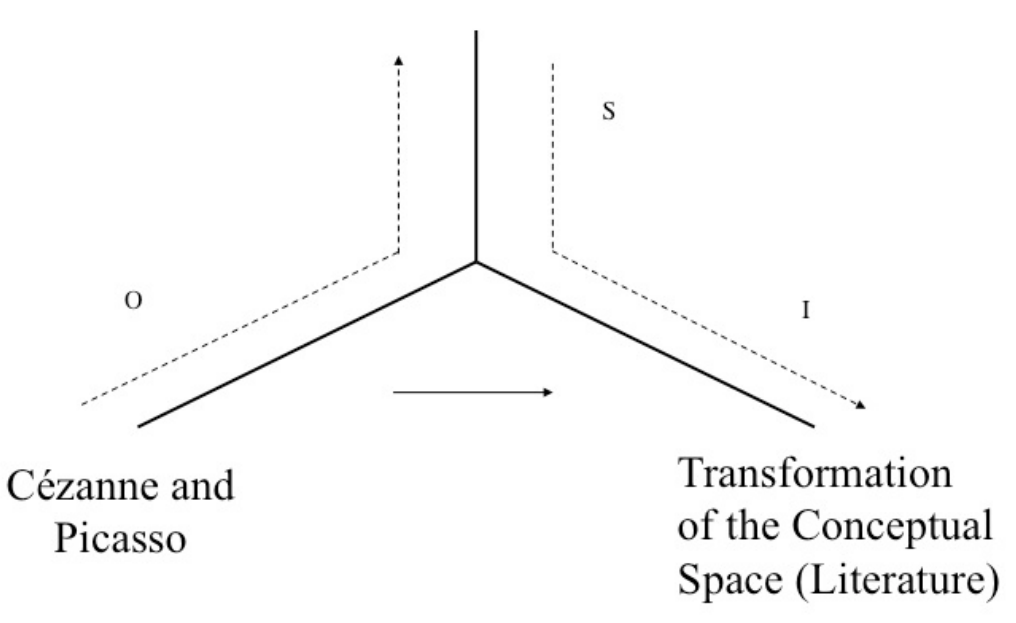

Figure 4. Gertrude Stein transformational IT from Cézanne and Picasso. A habit is communicated from proto-cubist and cubist painting, mediated by Stein's work, to the interpretant, which is a transformation of the conceptual space of literature.

We exemplify below with a written portrait by Stein named Picasso (1912) and a painting by Picasso called Ma Jolie (1911-1912) (see Figure 5). 


\section{Fragment from Picasso}

One whom some were certainly following was one who was completely charming. One whom some were certainly following was one who was charming. One whom some were following was one who was completely charming. One whom some were following was one who was certainly completely charming.

Some were certainly following and were certain that the one they were then following was one working and was one bringing out of himself then something. Some were certainly following and were certain that the one they were then following was one bringing out of himself then something that was coming to be a heavy thing, a solid thing and a complete thing.

One whom some were certainly following was one working and certainly was one bringing something out of himself then and was one who had been all his living had been one having something coming out of him.

Something had been coming out of him, certainly it had been coming out of him, certainly it was something, certainly it had been coming out of him and it had meaning, a charming meaning, a solid meaning, a struggling meaning, a clear meaning (Stein 1974 [1912]: 213).

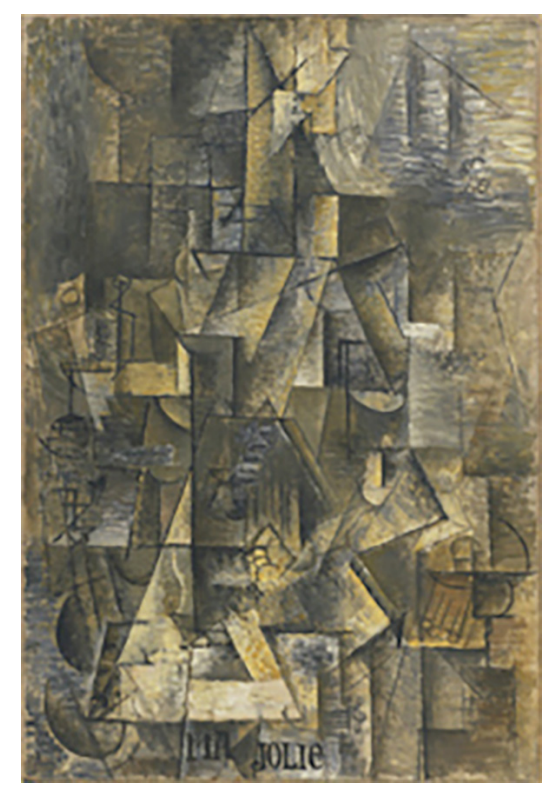

Figure 5. Ma Jolie by Pablo Picasso (1911-12).

In Picasso and in Ma Jolie the vocabulary is extremely restricted. The painting presents the brown and gray hues characteristic in Picasso and Braque's analytic phase, with slight variations. Stein uses a reduced number of vocables, repeated in different positions, unusually arranged, suggesting the multiple perspectives of Picasso. In Ma Jolie the composition is based on the superposition and interpenetration of diverse cubic rectilinear semi-transparent planes, producing a multiperspective geometry of the object.

It is also notable that the metonymic procedure is dominant (see Heldrich 1997; Scobie 1997, 1988). The portraits are constructed through extractions or fragments juxtaposed by contiguity. In Picasso, there are affirmative sentences of an observed situation, juxtaposed, in a translation of Picasso's procedure. ${ }^{6}$

Abreu (2008: 76) indicates another common element between Stein's writing and Picasso's painting: 'Both wanted to preserve each individual moment of perception in the present before those moments were systematized, by the intellectual knowledge of reality, in a concept of the object as it is "known"' (Abreu 2008: 76). In this way, according to Abreu, the influence by Cézanne over both of them is visible through the common interest in the perception process of the time. 


\section{Conclusion}

We have described IT as an irreducible triadic relation between conceptual spaces through habits and change of habits. In our example, Gertrude Stein's cubist prose may be defined as a medium for the communication of a regular pattern of sign-action (habit) found in Cézanne and Picasso's paintings. As a medium, Stein's prose is essentially in a triadic relation, to Cézanne and Picasso's paintings, which determine it, and to some effects on the conceptual space, which it transforms. That which is communicated from Cézanne and Picasso's paintings through Stein's prose to the conceptual space is a regular pattern of semiotic action.

Among the advantages of our approach, we mention: criteria to define a type of creative IT (transformational creativity) in the domain of Translation Studies, associating Boden's framework to describe a cognitive creative phenomenon with a philosophically robust theory of meaning, resulting in a cognitive semiotic account of IT. While Boden's approach is more concerned with the description of the effects of transformational creativity, our association suggests a possible semiotic operation to achieve such effects.

Our IT model offers a protocol to identify the relational dynamic between the creation of new artworks and artistic paradigms and their probable sources. Regarding the source of the IT (object), our model provides a criterion to identify which properties and concepts are relevant in an account of a conceptual space (e.g., the habits translated by Stein reveal relevant properties in proto-cubist and cubist painting). Regarding the target source of the IT (sign), our model helps to explain how the conceptual space is transformed.

Additionally, this perspective suggests a general model of the history of new artworks and artistic movements as IT processes. According to this model, art evolution should be understood as a translationally organized semiotic process. S, O and I become historical functional roles of the communication and transformation of habits. The inner relations and constraints between the three irreducible terms substitute the notions of 'influence' and 'inspiration' between artists, artworks and artistic movements. Further investigations are needed to explore this suggestion.

Acknowledgement: Pedro Atã would like to acknowledge the support received from CAPES Foundation, Ministry of Education of Brazil, Brasília-DF 70040-020, Brazil.

\section{NOTES}

${ }^{1}$ We shall follow the practice of citing from the Collected Papers of Charles Sanders Peirce (1931-1935, 1958) by volume number and paragraph number, preceded by 'CP'; the Essential Peirce by volume number and page number, preceded by 'EP'. References to the microfilm edition of Peirce's papers (Harvard University) will be indicated by 'MS', followed by the manuscript number.

${ }^{2}$ For further discussion on how sign, object and interpretant are causally related in semiosis, see Atkin (2015).

3 The reader should be aware that this model is a simplification of a complex multi-hierarchical process involving several layers of description. Thus, its aim here is to highlight some relevant properties to explain a complex phenomenon.

${ }^{4}$ Boden also acknowledges the possibility of psychological creativity and historical creativity. The first is related to the processes involving an individual kind of creativity; the second involves the creation of something new in human history. We are interested here in the historical one.

${ }^{5}$ It is not trivial to explain what is new and what is valuable. Their evaluation depends on negotiation by social groups (Boden 1999: 351). 
'In 'Portraits and Repetition' (Stein 1974: 115), Stein describes how her portraits result from a 'direct observation', not mediated by the memory or the object.

\section{REFERENCES}

Abreu, Andreia Manoela Passos de 2008. Gertrude Stein e o Cubismo Literário. Master thesis, Universidade Aberta.

Aguiar, Daniella and João Queiroz 2013. Semiosis and intersemiotic translation. Semiotica 196: 283292.

Aguiar, Daniella and João Queiroz 2010. Modeling intersemiotic translation: Notes toward a Peircean approach. AS/SA 9 (24): 68-81. Available from: http://french.chass.utoronto.ca/as-sa/ASSA-No24/ Articleben.htm. [Accessed August 2, 2015].

Apollinaire, Guillaume 1949. The cubist painters: aesthetic meditations. Trans. Lionel Abel, New York: Wittenborn Schultz.

Atkin, Albert 2015. Peirce. London: Routledge.

Bergman, Mats and João Queiroz (orgs.) 2014. The Commens Encyclopedia - The Digital Encyclopedia of Peirce Studies. 1. ed. Helsinki: Creative Commons. Available from: http://www.commens. org/encyclopedia [accessed: August 28, 2015]

Boden, Margaret A. 2010. Creativity and Art: Three Roads to Surprise. Oxford: Oxford University Press.

Boden, Margaret A. 1999. Computer Models of Creativity. In: Robert J. Sternberg (ed.), Handbook of Creativity. New York: Cambridge University Press, 351-372.

Clüver, Claus 2011. Intermidialidade. Pós 1 (2): 8-23.

Clüver, Claus 2006. Da Transposição Intersemiótica. In: Márcia Arbex (org.), Poéticas do visível: ensaios sobre a escrita e a imagem. Belo Horizonte: Programa de Pós-Graduação em Letras - Estudos Literários, Faculdade de Letras da UFMG, 107-166.

Clüver, Claus 1981. Klangfarbenmelodie in Polychromatic Poems: A. Von Webern and A. de Campos. Comparative Literature Studies 18 (3): 386-398.

De Tienne, André 2003. Learning qua semiosis. S.E.E.D. 3: 37-53.

Dubnik, Randa 1984. The Structure of Obscurity: Gertrude Stein, Language, and Cubism. Urbana: University of Illinois Press.

Fitz, Linda T. 1973. Gertrude Stein and Picasso: The Language of Surfaces. American Literature 45 (2): 228-37.

Franken, Claudia 2000. Gertrude Stein, writer and thinker. Münster: LitVerlag.

Gass, William H. 1995. Foreword. In: Gertrude Stein, The Making of Americans: being a history of a family's progress. Normal (IL): Dalkey Archive Press, vii-xi.

Gonzalez, Maria Eunice Quilici and Willem Ferdinand Gerardus Haselager 2005. Creativity: Surprise and Abductive Reasoning. Semiotica 153 (1): 325-342.

Hausman, Carl R. 1993. Charles S. Peirce's evolutionary philosophy. Cambridge: Cambridge University Press.

Hejinian, Lyn 2000. Two Stein Talks. In: Lyn Hejinian (ed.), The Language of Inquiry. Berkeley: University of California Press, 83-130.

Heldrich, Philip 1997. Connecting surfaces: Gertrude Stein's three lives, cubism, and the metonymy of the short story cycle. Studies in Short Fiction 34 (4): 427-440.

Hilder, Jamie 2005. 'After All One Must Know More than One Sees and One Does Not See a Cube in Its Entirety': Gertrude Stein and Picasso and Cubism. Critical Survey 17 (3): 66-84.

Hoffman, Michael J. 1965. The Development of Abstractionism in the Writings of Gertrude Stein. Philadelphia: University of Pennsylvania Press. 
Hookway, Christopher 1985. Peirce. London: Routledge and Kegan Paul.

Hulswit, Menno 2001. Semeiotic and the cement of the universe: a Peircean process approach to causation. Transactions of the Charles S. Peirce Society: A Quarterly Journal in American Philosophy 37 (3): 339-363.

Jakobson, Roman 2000. On Linguistic Aspects of Translation. In: Lawrence Venuti (ed.), The Translation Studies Reader. London and New York: Routledge, 113-118.

Kissane, Seán (ed.) 2010. Vertical thoughts: Morton Feldman and the visual arts. Dublin: Irish Museum of Modern Art.

Levinson, Ronald B. 1941. Gertrude Stein, William James, and Grammar. The American Journal of Psychology 54 (1): 124-28.

Magnani, Lorenzo 2005. An abductive theory of scientific reasoning. Semiotica 153 (1): 261-286.

Nath, Kirsten and Kathrin Matthes 2005. Hemingway and Stein. Gertrude Stein's Influence on Ernest Hemingway's For Whom the Bell Tolls. Munich: GRIN Verlag.

Peirce, Charles S. 1992/1998. The Essential Peirce, Selected Philosophical Writings. Vol. 1, Nathan Houser and Christian Kloesel (eds.); Vol 2, Peirce Edition Project (ed.), Bloomington and Indianapolis: Indiana University Press, EP1 1992, EP2 1998. (Quoted as EP).

Peirce, Charles S. 1931-1935. The Collected Papers of Charles Sanders Peirce. Electronic edition reproducing. Vols. I-VI, Charles Hartshorne and Paul Weiss (eds.), Cambridge: Harvard University Press, 1931-1935; Vols. VII-VIII, Arthur W. Burks (ed.), Cambridge: Harvard University Press, 1958. Charlottesville: Intelex Corporation, 1931-1935. (Quoted as CP).

Peirce, Charles S. 1967. Annotated Catalogue of the Papers of Charles S. Peirce. Richard S. Robin (ed.), Massachusetts: The University of Massachusetts Press. (Quoted as MS).

Perloff, Marjorie 1979. Poetry as Word-System: The Art of Gertrude Stein. The American Poetry Review 8 (5): 33-43.

Picasso, Pablo 1911-1912. Ma Jolie. Museum of Modern Art. Available from: http://www.moma.org/ collection/works/79051 [accessed: August 28, 2015]

Queiroz, João and Daniella Aguiar 2015. C. S. Peirce and Intersemiotic Translation. In: Peter Pericles Trifonas (ed.), International Handbook of Semiotics. Netherlands: Springer, 201-215.

Queiroz, João and Charbel El-Hani 2006. Semiosis as an emergent process. Transactions of the C.S. Peirce Society 42 (1): 78-116.

Queiroz, João and Charbel El-Hani 2004. Towards a multi-level approach to the emergence of semiosis in semiotic systems. Technical Report, DCA-FEEC, UNICAMP, número 04-07.

Rajewsky, Irina 2005. Intermediality, Intertextuality, and Remediation: A Literary Perspective on Intermediality. Intermédialités 6: 43-64.

Retallack, Joan 2008. Introduction. In: Joan Retallack (ed.), Gertrude Stein: Selections. Berkeley: University of California Press, 3-81.

Ritchie, Graeme 2005. On transformational creativity. Proceedings of the Computational Creativity Workshop, IJCAI.

Scobie, Stephen 1997. Metaphor and metonymy in cubism and Gertrude Stein. In: Stephen Scobie (ed.), Earthquakes and explorations: language and painting from cubism to concrete poetry: chapter six. Toronto: University of Toronto Press, 104-123.

Scobie, Stephen 1988. The Allure of Multiplicity: Metaphor and Metonymy in Cubism and Gertrude Stein. In: Shirley Neuman and Ira B. Nadel (eds.), Gertrude Stein and the making of literature. Boston: Northwestern University Press.

Stein, Gertrude 1974. Portraits and Repetition. In: Patricia Meyerowitz (ed.), Gertrude Stein, Writings and lectures: 1909-1945. Baltimore: Penguin Books, 99-124.

Stein, Gertrude 1974 [1912]. Picasso. In: Patricia Meyerowitz (ed.), Gertrude Stein, Writings and lectures: 1909-1945. Baltimore: Penguin Books, 213-215. 
Sternberg, Robert J. and Todd I. Lubart 1999. The concept of creativity: prospects and paradigms. In: Robert J. Sternberg (ed.), Handbook of Creativity. New York: Cambridge University Press, 3-15.

Verdi, Richard 1968. Musical influences on the art of Paul Klee. Art Institute of Chicago Museum Studies 3: 81-107.

Weinstein, Norman 1970. Gertrude Stein and the Literature of the Modern Consciousness. New York: Frederick Ungar Publishing.

Weiss, M. Lynn 1998. Gertrude Stein and Richard Wright: The Poetics and Politics of Modernism. University Press of Mississipi.

Weiss, Peg 1997. Evolving Perceptions of Kandinsky and Schoenberg: Toward the Ethnic Roots of the 'Outsider'. In: Juliane Brand and Christopher Hailey (eds.), Constructive Dissonance: Arnold Schoenberg and the transformations of the twentieth-century culture. Berkeley: University of California Press, 35-57.

Daniella Aguiar is Professor at the Institute of Arts, Federal University of Uberlândia (UFU), and member of the Iconicity Research Group [irg].

Email: daniella.aguiar@gmail.com

Pedro Atã is a graduate student at the MA in Arts, Culture and Languages at the Institute of Arts, Federal University of Juiz de Fora (UFJF), and member of the Iconicity Research Group [irg].

Email: ata.pedro.1@gmail.com

João Queiroz is Professor at the Institute of Arts and Design, Federal University of Juiz de Fora (UFJF). He is a director member of the International Association for Cognitive Semiotics (IACS), member of the Linnaeus University Centre for Intermedial and Multimodal Studies, and director of the Iconicity Research Group [irg].

Email: queirozj@gmail.com 